\title{
Assessment of reclaimed water irrigation on growth, yield, and water-use efficiency of forage crops
}

\author{
S. A. Alkhamisi • H. A. Abdelrahman • \\ M. Ahmed - M. F. A. Goosen
}

Received: 3 February 2011/ Accepted: 18 July 2011/Published online: 4 August 2011

(c) The Author(s) 2011. This article is published with open access at Springerlink.com

\begin{abstract}
Field experiments were conducted to determine the effect of water quality (reclaimed and fresh water), water quantity, and their interactions on the growth, yield, and water use efficiency of forage maize during two winter seasons in the Arabian Gulf. The plants irrigated with the reclaimed water had higher plant height than those irrigated with the fresh water. The leaf length and leaf area $\left(\mathrm{cm}^{2}\right)$ did not show any significant differences among the interaction. Reclaimed water had shorter time for $50 \%$ male and female flowering of forage maize plants, indicating earlier maturity. Plants irrigated with reclaimed water had higher chlorophyll content for all levels of water applications. A significant difference in green forage yield was found among the interactions. Reclaimed water gave the highest green forage yield of 72.12 and $59.40 \mathrm{t} / \mathrm{ha}$ at 1.4ETo and 1.0ETo, respectively. Plants irrigated with the reclaimed water used water more efficiently $\left[3.65 \mathrm{~kg} / \mathrm{m}^{3}\right.$ of DM (dry matter)] than those irrigated with the fresh water $\left[2.91 \mathrm{~kg} / \mathrm{m}^{3}\right.$ of $\mathrm{DM}$ (dry matter)] for all water quantities. The enhanced growth in wastewater-irrigated crops, compared with fresh waterirrigated crops, was attributed primarily to higher nutrient
\end{abstract}

\section{S. A. Alkhamisi}

Ministry of Agriculture, Muscat, Sultanate of Oman

e-mail: saif.alkhamisi@gmail.com

H. A. Abdelrahman $(\bowtie) \cdot$ M. Ahmed

Department of Soils, Water and Agricultural Engineering,

Sultan Qaboos University, Muscat, Sultanate of Oman

e-mail: hayderar@squ.edu.om

M. Ahmed

e-mail: ahmedm@squ.edu.om

\section{F. A. Goosen}

Office of Research and Graduate Studies,

Alfaisal University, Riyadh, Saudi Arabia

e-mail: mgoosen@alfaisal.edu content (e.g., nitrogen) and lower salinity of the reclaimed water. The study concluded that treated wastewater irrigation increased yields of forage crops and their water use efficiency. Cost-benefit analysis, studies on the use these forage crops as animal feed, and more in depth evaluation of possible crop and soil contamination were recommended.

Keywords Reclaimed Water - Zea mays - Forage crops · Wastewater Management $\cdot$ Nutrients
Abbreviation
BOD Biological Oxygen Demand (mg/l)
COD Chemical Oxygen Demand ( $\mathrm{mg} / \mathrm{l})$
C4 Carbon 4
DM Dry matter
ECe Electric Conductivity of the saturation extract,
$\mathrm{dS} / \mathrm{cm})($ deci-Siemens per centimeter)
ETo Reference evapotranspiration $\left(\mathrm{m}^{3}\right.$ or $\left.\mathrm{mm}\right)$
ETc Crop evapotranspiration $\left(\mathrm{m}^{3}\right.$ or $\left.\mathrm{mm}\right)$
FAO Food and Agriculture Organization,
FW Fresh water
Kc Crop factor
LSD Least Significant difference
NUE Nitrogen use efficiency
$\mathrm{pH} \quad$ Minus log hydrogen concentration
RW Reclaimed water
WUE Water use efficiency $\left(\mathrm{kg} / \mathrm{m}^{3} \mathrm{DM}\right)$

\section{Introduction}

Reclaimed water such as treated wastewater is an important source of non-conventional water which is currently used

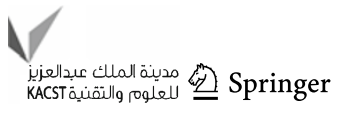


for agricultural irrigation, aquifer recharge, fish culture, cooling, and construction (Alade and Ojoawo 2009; Carr et al. 2011; Chenini 2011; Wu and Margulis 2011; da Fonseca et al. 2005; Vazquzio et al. 1996; Mohamed 1983). Studies have also been done on the effects of treated municipal waste water on soil chemical properties and heavy metal uptake by forage crops (Galavi et al. 2010; Abaidoo et al. 2010). Furthermore, the use of reclaimed water is of particular importance to arid regions of the world (Abdelrahman et al. 2009) such as the Arabian Gulf (MRMEWR 2005).

Parsons et al. (2010) reported that high application rates of reclaimed water to citrus increased tree growth and fruit production. However, there was insufficient macronutrient content in the reclaimed water to meet plant nutritional requirements. In a related study, municipal reclaimed water has also been used for turfgrass irrigation (Evanylo et al. 2010). Moreover, Qadir et al. (2010) reported that the use of reclaimed water has increased, as millions of small-scale farmers in urban areas of developing countries depend on wastewater or polluted water sources to irrigate high-value edible crops for urban markets. Concern was expressed about the harm to human health.

Mohammad and Ayadi (2004) noted that the uptake of macro and micronutrients by corn increased with reclaimed water irrigation, implying that secondary reclaimed water could be a source of plant nutrients and can be reused for irrigation to increase forage crop production. Tavassoli et al. (2010) reported a major increase in fresh and dry forage yield of corn irrigated with reclaimed water with a significant influence on crude protein content, ash percentage, and macro elements (i.e., N, P and K). Bouchaib et al. (1999) found that treated water applications attenuated the detrimental effects of water salinity on crops. Mohammad and Mazahareh (2003) noted that reclaimed water irrigation decreased soil $\mathrm{pH}$ and increased soil salinity, soil phosphorus $(\mathrm{P})$, potassium $(\mathrm{K})$, iron $(\mathrm{Fe})$, and manganese $(\mathrm{Mn})$ levels, but soil organic matter was increased only in the topsoil. In a related investigation, Abdelrahman and Al-Ajmi (1994) reported that 4-8 years of continuous irrigation with reclaimed water did not produce any hazardous levels of heavy metal deposition in soils.

Maize has high irrigation requirements and is very sensitive to water stress (Rhoads and Bennett 1990; Akhtar and Nadaf 2002). Alessi and Power (1976) reported that water-use efficiency of corn dry matter at a plant population of 74,000 plants per hectare was $2.65 \mathrm{~kg} \mathrm{~m}^{-3}$. The water use efficiency for well-watered corn ranged from $1.2 \mathrm{~kg} \mathrm{~m}^{-3}$ in Bushland, Texas (Musik and Duesk 1980) to $3.5 \mathrm{~kg} \mathrm{~m}^{-3}$ in Fayum, Egypt (Mohammad, and Ayadi 2004), and as high as $5 \mathrm{~kg} \mathrm{~m}^{-3}$ at Bet Oagan, Israel (Yanuka et al. 1982).
The objectives of this study were to assess the effect of using reclaimed water as an alternative source to irrigate maize (Zea mays L.) crop for forage and to identify the yield and water use efficiency of forage maize under reclaimed water irrigation.

\section{Methodology}

Two field experiments were conducted during the winter seasons of 2006/07 and 2007/08 at the Agricultural Research Center, Rumais, Sultanate of Oman (58 0036 E-23 $4056 \mathrm{~N}$ ). A randomized complete block split-plot design (RCBD) was adopted with four replications consisting of factorial combinations of two types of irrigation water and three water quantities. The three water quantity treatments $(0.6 \mathrm{ETo}, 1.0 \mathrm{ETo}$ and $1.4 \mathrm{ETo})$ represented the main plots, whereas the two types of irrigation water, i.e., tertiary reclaimed water and fresh water were the sub-main plots (Table 1). For the irrigation treatments, the average emitter discharge was used to administer water for a given time to give the required depth. Differences in emitter discharges resulted in slight differences in the application rate (i.e., depth applied).

The study area was divided into 24 plots consisting of four blocks (replicates), each having six plots (two types of water multiplied by three water quantities). The area of each plot was $6 \mathrm{~m}^{2}$ with two meters of spacing in between. The recommended maize variety Hyb901 (Australia) was used in these experiments. Sowing was commenced on the 4th of December 2006, and harvesting was carried out on the 8th of March 2007 in the first season, whereas in the second season the sowing date was on the 24th of December 2007 and harvesting was carried out on the 20th of March 2008. Planting was done on ridges along the drip lines with a row spacing of 50 and $25-\mathrm{cm}$ between the drippers. Each plot contained 48 plants in four lines. For the maize crop grown as green fodder, the seed rate varies between 65 and $75 \mathrm{~kg} / \mathrm{ha}$. Two seeds were located adjacent to the dripper to insure germination then thinned later to one plant. The optimum plant population maintained was around 40,000-50,000 plants/ha as recommended by (Akhtar and Nadaf 2002). For our study the total cropped area was $192 \mathrm{~m}^{2}$; four water rates and two water types replicated four times or 32 plots each having an area of $6 \mathrm{~m}^{2}$. Each plot contained 48 drippers (plants) or 172 plants for each treatment. The $6-\mathrm{m}^{2}$ plots are common in the area for surface irrigation.

The source of fresh water was the groundwater at the Agricultural Research Center, Rumais, which is located close to the sea (i.e., Gulf of Oman). The latter could result in elevated sodium and chloride concentrations (Table 2) due to seawater intrusion into the water table. 
Table 1 Total amount $\left(\mathrm{m}^{3}\right)$ and depth of water $(\mathrm{mm})$ applied during the two seasons

\begin{tabular}{|c|c|c|c|c|c|c|c|c|}
\hline \multirow[t]{3}{*}{ Treatment } & \multicolumn{4}{|c|}{ Season $2006 / 2007$} & \multicolumn{4}{|c|}{ Season $2007 / 2008$} \\
\hline & \multicolumn{2}{|l|}{ Fresh water } & \multicolumn{2}{|c|}{ Reclaimed water } & \multicolumn{2}{|l|}{ Fresh water } & \multicolumn{2}{|c|}{ Reclaimed water } \\
\hline & Volume $\left(\mathrm{m}^{3}\right)$ & Depth (mm) & Volume $\left(\mathrm{m}^{3}\right)$ & Depth (mm) & Volume $\left(\mathrm{m}^{3}\right)$ & Depth (mm) & Volume $\left(\mathrm{m}^{3}\right)$ & Depth (mm) \\
\hline 1.4 ETo & 2.883 & 481 & 2.820 & 470 & 3.151 & 525 & 3.122 & 520 \\
\hline 1.0 ETo & 2.169 & 362 & 2.121 & 354 & 2.493 & 415 & 2.424 & 404 \\
\hline 0.60 ETo & 1.486 & 248 & 1.409 & 235 & 1.812 & 302 & 1.731 & 289 \\
\hline
\end{tabular}

The tertiary-treated reclaimed domestic water was transported from the Al-Manoumah Sewage Treatment Plant (9 $\mathrm{km}$ away). Water samples were analyzed for cations, anions, and trace elements (Table 2). Six water meters, one for each treatment, were installed to determine the amount of water applied. The three water quantities were administered according to the reference evapotranspiration (ETo) as shown in Table 1. They were altered during the different stages of the crop growth (i.e., initial, development and late stages) according to the crop factor. Irrigation water was administered every 3 days.

Irrigation water was applied to compensate for what was lost by evapotranspiration during the previous 3 days $(\mathrm{ETc})$, where $\mathrm{ETc}=K \mathrm{c} \times$ ETo and $K \mathrm{c}$ is the crop coefficient for that stage. The reference evapotranspiration (ETo) was expressed in terms of depth (i.e., $\mathrm{mm}$ ) and then transformed to volume (i.e., cubic meter) through multiplying by the area of the plot. The crop coefficient $(K \mathrm{c})$ for maize crop was $0.7,1.2$, and 0.6 for the initial, development, and late stages of growth, respectively (Dorenbos and Pruitt 1992). ETo was calculated using the Pen man Monteeth method (Dorenbos and Pruitt 1992). The climatic data (Table 3) were obtained from Rumais Metrological Station, Directorate General of Agricultural and Livestock Research.

Soil samples were analyzed for physical attributes and electrical conductivity of the saturation extract (ECe) and $\mathrm{pH}$ before planting and after harvest according to "methods of analysis for soils, plants and waters" (Chapman and Pratt 1982). The texture of the soil used in the study was found to be loamy sand with a bulk density of $1.65 \mathrm{~g} / \mathrm{cm}^{3}$. The average ECe values for the reclaimed water treatments were 9.0 and $5.5 \mathrm{dS} / \mathrm{m}$ before planting and at harvest, respectively, for the first season and, 2.6 and $1.9 \mathrm{dS} / \mathrm{m}$ for the second season. The corresponding values for the fresh water treatments were $4.2 \mathrm{dS} / \mathrm{m}$ before planting and at harvest for the first season and $2.0 \mathrm{dS} / \mathrm{m}$ for the second season, respectively. The average soil $\mathrm{pH}$ value was around 8.0 in all cases. The crop was harvested when it reached $50 \%$ flowering stage. For the current 2-year study this occurred on 8 March 2007 and 20 March 2008. The plants were cut from top of the land surface. Each plot was harvested and weighed separately and the inner two lines were weighed using a top pan balance. Samples of two plants were taken to the laboratory, weighed, and dried in an oven at a temperature of $70^{\circ} \mathrm{C}$ for 3 days. Yield parameters of green fodder were recorded during the harvest day. Plant samples were collected from each plot at harvest for the dry biomass and from the chemical analysis in the laboratory. The plant height $(\mathrm{cm})$ and the green and dry forage yield ( $\mathrm{t} / \mathrm{ha}$ ) were collected and recorded.

Agronomic characteristics like number of leaves per plant, leaf length, and leaf area were also taken during different stages of plant growth. When plants were in the late stage (male inflorescence) then the leaf chlorophyll content was evaluated by using a portable chlorophyll meter (Minolta-SPAD-502 Model). Four readings from the seventh leaf (Cob Leaf) from the six tagged plants per experimental unit (plot) were taken. The values measured by the Chlorophyll Meter (SPAD-502) corresponded to the amount of chlorophyll present in the plant leaf. These values were calculated based on the amount of light transmitted by the leaf in two wavelength regions in which the absorbance of chlorophyll is different. Leaf area was measured using a leaf area meter type CI-202. Three leaves were taken from six plants in each plot. In addition, leaf lengths of the same plants were measured using a ruler. The protein content was determined from the percentage of nitrogen in the leaves multiplied by a Jones factor of 6.25 as described by Merrill and Watt (1973).

Six plants were tagged for growth rate measures. The plant height $(\mathrm{cm})$ was measured using a ruler, and the leaves were counted weekly 30 days after planting to calculate the growth rate of the treatments. The growth rate was calculated using the following equation:

$R n=\frac{(X n)-(X n-1)}{7}$

where:

$R n=\quad$ Growth rate in the week $n(\mathrm{~cm} / \mathrm{day} /$ week $)$

$n=\quad$ Number of the week from the starting of the experiment

$X n=\quad$ Plant height $(\mathrm{cm})$ in the week $n$ 
Table 2 Elemental analyses of water samples

\begin{tabular}{|c|c|c|}
\hline & $\begin{array}{l}\text { Reclaimed } \\
\text { water }\end{array}$ & $\begin{array}{l}\text { Fresh } \\
\text { water }\end{array}$ \\
\hline Average conductivity $(\mathrm{EC} \mathrm{dS} / \mathrm{m})$ & 1.11 & 1.29 \\
\hline $\mathrm{pH}$ & 7.9 & 7.0 \\
\hline Nitrogen $(\mathrm{N}$ mg/l) & 29.9 & 0.362 \\
\hline Phosphorus (P) & Trace & Trace \\
\hline Biological Oxygen Demand (BOD mg/l) & 5 & - \\
\hline Chemical Oxygen Demand (COD mg/l) & 90 & - \\
\hline \multicolumn{3}{|l|}{ Cations and Anions (mg/l) } \\
\hline Calcium $\left(\mathrm{Ca}^{2+}\right)$ & 42 & 10 \\
\hline Magnesium $\left(\mathrm{Mg}^{2+}\right)$ & 15 & 19 \\
\hline Sodium $\left(\mathrm{Na}^{+}\right)$ & 75 & 114 \\
\hline Potassium $\left(\mathrm{K}^{+}\right)$ & 13 & 1.8 \\
\hline Chloride $\left(\mathrm{Cl}^{-}\right)$ & 116.2 & 270.4 \\
\hline Sulfate $\left(\mathrm{SO}_{4}{ }^{-}\right)$ & 72.6 & 10 \\
\hline Sodium Adsorption Ratio (SAR) & 14.0 & 29.9 \\
\hline \multicolumn{3}{|l|}{ Trace Elements $(\mu \mathrm{g} / \mathrm{l})$} \\
\hline Cadmium $(\mathrm{Cd})$ & ND & ND \\
\hline Cobalt (Co) & ND & ND \\
\hline Chromium $(\mathrm{Cr})$ & ND & ND \\
\hline Copper $(\mathrm{Cu})$ & 2.60 & 1.67 \\
\hline Iron $(\mathrm{Fe})$ & 2.02 & 111.0 \\
\hline Manganese (Mn) & 0.01 & 15.3 \\
\hline Molybdenum (Mo) & ND & ND \\
\hline Nickel (Ni) & 0.223 & 0.82 \\
\hline Lead $(\mathrm{Pb})$ & ND & ND \\
\hline Vanadium $\mathrm{V}$ & 0.306 & ND \\
\hline Zinc $(\mathrm{Zn})$ & ND & 63.5 \\
\hline
\end{tabular}

ND Not detected

$X n-1=$ Plant height $(\mathrm{cm})$ in the previous week of the week $n$

$7=\quad$ Constant, number of days per week (days)

The water use efficiency (WUE) is the ratio of dry matter gained to water lost by evapotranspiration:

$\mathrm{WUE}=\frac{\text { Yieldperunitarea }(\mathrm{kg})}{\text { Water used to produce that yield }\left(\mathrm{m}^{3}\right)}$

WUE was used to compare the reclaimed water with fresh water as well as the quantities of irrigation water.
The data were statistically analyzed using the Analysis of Variance method (ANOVA) according to Gomez and Gomez (1984) using computer programs (SPSS and MstatC softwares) and the means were subjected to the Feisher's F-test.

\section{Results and Discussion}

The growth of plants increased slowly during the first 6 weeks in all treatments (Fig. 1). From the sixth week onward the growth started increasing sharply. The growth rate factor in terms of plant height for the treatments is shown in Fig. 2. The rate of growth decreased in weeks 8 and 9 for some treatments since during that time the crop had reached the flowering stage. Treatments with elevated amounts of water resulted in higher growth rates. Plants irrigated with reclaimed water had higher development rates in comparison with those irrigated with fresh water suggesting the presence of nutrients, as indicated in Table 2. This is similar to results reported by others (Parsons et al. 2010; Qadir et al. 2010; Evanylo et al. 2010).

The analysis of variance indicated that there were significant differences $(p<0.05)$ among interaction of quantity and quality of water used. Treatments receiving 1.4ETo were highly significant $(p<0.05)$ for plant height than the 1.0ETo and 0.6ETo treatments. In turn treatments receiving 1.0ETo were significantly $(p<0.05)$ higher than the 0.6ETo treatments (Table 4). The tallest maize plants were achieved by reclaimed water with 1.4ETo water quantity $(177.93 \mathrm{~cm})$ and 1.0ETo $(157.07 \mathrm{~cm})$ followed by $1.4 \mathrm{ETo}$ water quantity $(133.99 \mathrm{~cm})$ in fresh water. The water quantities of 1.4ETo $(133.9 \mathrm{~cm}), 1.0$ ETo $(127.27 \mathrm{~cm})$, $0.6 \mathrm{ETo}(116.71 \mathrm{~cm})$ in fresh water type and $0.6 \mathrm{ETo}$ $(120.57 \mathrm{~cm})$ of the reclaimed water were not significantly different. Generally, the reclaimed water gave the highest plant height in comparison with the fresh water. This result could be attributed to higher amounts of nutrients, especially nitrogen in the reclaimed water (Table 2). Parsons et al. (2010) also reported on the importance of nutrients, such as nitrogen, in reclaimed water and their positive effects on plant growth. Since no additional nutrients were added to any of the treatments in our study, reclaimed

Table 3 Average monthly meteorological data summary for the experimental site during 2007-2008

\begin{tabular}{|c|c|c|c|c|c|c|}
\hline Month & Max temp $\left({ }^{\circ} \mathrm{C}\right)$ & Min temp $\left({ }^{\circ} \mathrm{C}\right)$ & Rainfall (mm) & RH max $(\%)$ & $\mathrm{RH} \min (\%)$ & Reference ET (mm) \\
\hline December & 24.68 & 17.55 & 0.23 & 78.77 & 47.35 & 2.82 \\
\hline January & 23.56 & 15.52 & 0.01 & 71.62 & 43.48 & 3.20 \\
\hline February & 26.31 & 18.00 & 0.00 & 82.48 & 43.85 & 3.84 \\
\hline March & 28.59 & 19.52 & 0.44 & 82.68 & 35.64 & 5.01 \\
\hline April & 35.06 & 23.45 & 0.00 & 69.63 & 19.67 & 7.25 \\
\hline
\end{tabular}




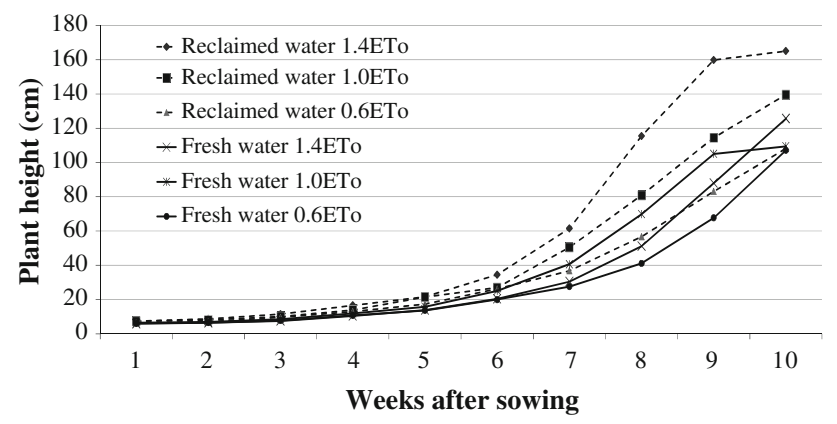

Fig. 1 Plant height of forage maize $(\mathrm{cm})$ irrigated with three quantities of reclaimed water and fresh water with time

water plots therefore yielded better growth rates by virtue of their higher nitrogen and possibly sulfate contents compared with fresh water (Table 2). For example, reclaimed water contained $29.9 \mathrm{mg} / \mathrm{l}$ nitrogen compared with only $0.362 \mathrm{mg} / \mathrm{l}$ for fresh water. Furthermore, in the current study it is important to note that the Agricultural Experiment Station at Rumais is situated next to the sea (i.e., Gulf of Oman). There is a serious problem of seawater intrusion into the water table along the coast due to over extraction (i.e., pumping) of ground water for agricultural purposes. This would account for the higher sodium and chloride concentration in the fresh water as compared with the reclaimed water which was trucked in from a domestic sewage plant $9 \mathrm{~km}$ away (Table 2). The higher salt content in the fresh water would have helped to reduce growth rates.

The mean data on days to $50 \%$ male and female flowering in the current study are presented in Table 4, along with statistical parameters. The results indicated that the quality of water applied significantly $(p<0.05)$ affected the days of $50 \%$ male flowering. However, significant differences were found among the levels of water quantity and their interaction with the type of irrigation water. Plants irrigated with fresh water took a longer time to $50 \%$ male flowering in comparison with those irrigated with the reclaimed water during the 2006/07 season. The shortest time that maize plants took to male flowering was achieved by the reclaimed water with $1.4 \mathrm{ETo}$ water quantity ( 81 days) followed by 1.0ETo ( 85 days). During the winter season $2007 / 08$ plants took a shorter time to $50 \%$ male flowering in comparison with those cultivated during the season 2006/07. On average, the longest time that maize plants took to male flowering was achieved by fresh water irrigated with $0.6 \mathrm{ETo}$ water quantity ( 85 days) followed by reclaimed water 0.6ETo (84 days) (Table 4).

With $50 \%$ female flowering, the analysis of variance showed a significant difference $(p<0.05)$ among the interaction between quantity and the type of irrigation water. Reclaimed water had a shorter time for $50 \%$ female flowering (84 days) than fresh water in 1.4ETo water quantity (91 days) during 2006/07 winter season (Table 4). The shortest time to $50 \%$ female flowering was achieved by $1.4 \mathrm{ETo}$ ( 80 days) and 1.0ETo ( 83 days) water quantities in reclaimed water, whereas the longest were in 0.6ETo at fresh water ( 89 days) followed by $0.6 \mathrm{ET}$ a at reclaimed water (87 days).

The results of statistical analysis indicated a significant difference in green forage yield $(p<0.05)$ among the interactions of quantity and quality of irrigation water. On the average of both seasons, no significant difference was found between the water quantities 1.4ETo and 1.0ETo in reclaimed water. However, a significant difference $(p<0.05)$ was found between the water quantities 1.0ETo and 0.6ETo in reclaimed water. The water quantities of $0.6 \mathrm{ETo}$ in fresh and reclaimed water were not significantly different from 1.0ETo in fresh water (Table 5). Reclaimed water gave higher green forage yield than fresh water type because $\mathrm{C} 4$ plants have greater photosynthetic nitrogen use efficiency (NUE) than C3 plants (Monson 1989). So, corn as a $\mathrm{C} 4$ plant has greater photosynthetic use efficiency and can metabolize the high levels of nitrogen from reclaimed water. The water quantities of 1.4ETo and 1.0ETo in reclaimed water gave the highest green forage yield (72.12 and $59.40 \mathrm{t} / \mathrm{ha}$, respectively). The water quantity of $0.6 \mathrm{ETo}$ produced the lowest green forage yield (43.13 $\mathrm{t} / \mathrm{ha}$ for the reclaimed water and $39.97 \mathrm{t} / \mathrm{ha}$ for fresh water) (Table 5).

Significant differences $(p<0.05)$ were also found for quantity and quality of irrigation water applied whereas no interaction effect was found on the leaf length $(\mathrm{cm})$. Water quantities of 1.4ETo $(81.67 \mathrm{~cm})$ and 1.0ETo $(81.95 \mathrm{~cm})$ which were not significantly different from each other, produced higher leaf length than 0.6ETo $(76.06 \mathrm{~cm})$ (Table 6). The mean leaf length was $77.89 \mathrm{~cm}$ in plants irrigated with fresh water and $81.90 \mathrm{~cm}$ in those irrigated reclaimed water (Table 7).

Regarding the dry matter yield, there were significant differences $(p<0.05)$ among the quantity and the type of applied irrigation water levels, whereas no significant differences were found among their interaction, which is the combined effects of the water quality (i.e., rates) and quality (i.e., type). Treatments receiving reclaimed water were significantly higher in dry matter yield than those treated with fresh water (19.48 and $15.47 \mathrm{t} / \mathrm{ha}$, respectively) (Table 8 ). The 1.4ETo (19.71 t/ha) and 1.0ETo water quantities (18.76 t/ha) significantly produced higher dry matter yield than 0.6ETo quantity (13.94 t/ha).

The analysis of variance of the leaf area $\left(\mathrm{cm}^{2}\right)$ showed a significant difference $(p<0.05)$ among the type of irrigation water applied, whereas no significant differences in the quantity and the interaction were noticed. Reclaimed water treatments had higher mean leaf area (615.64 vs. $572.37 \mathrm{~cm}^{2}$ ) for fresh water under different water quantities (Table 7). 
Fig. 2 Growth rates $(\mathrm{cm} /$ day $)$ represented in plant height of forage maize irrigated with fresh and reclaimed water and three quantities of irrigation water in 9 weeks

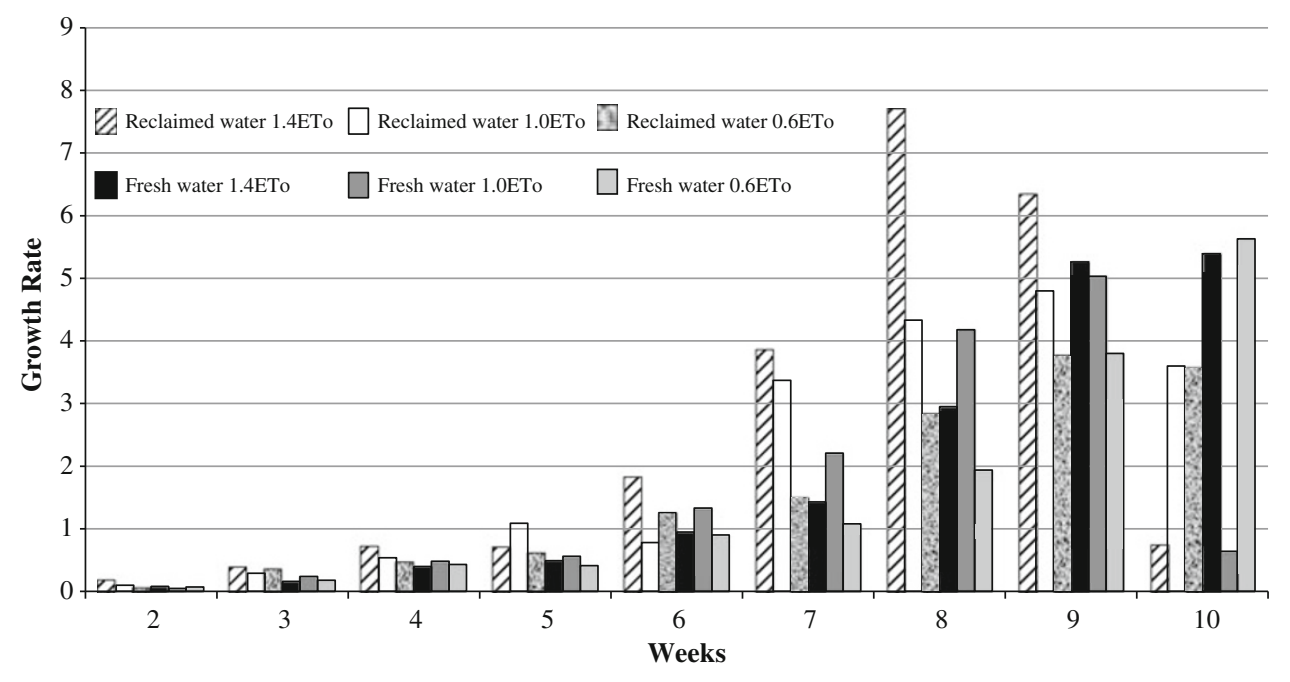

Table 4 Forage maize height (cm) for different quantities of irrigation water under fresh (FW) and reclaimed (RW) water in two winter seasons

\begin{tabular}{|c|c|c|c|c|c|c|}
\hline \multirow[t]{2}{*}{ Treatments } & \multicolumn{2}{|c|}{ Plant height $(\mathrm{cm})$} & \multicolumn{2}{|c|}{$50 \%$ male flowering } & \multicolumn{2}{|c|}{$50 \%$ female flowering } \\
\hline & RW & FW & RW & FW & RW & FW \\
\hline 1.4ETo & $177.93 \mathrm{a}$ & $133.99 \mathrm{bc}$ & $76 \mathrm{c}$ & $84 \mathrm{ab}$ & $80 \mathrm{c}$ & 87 a \\
\hline 1.0ETo & $157.07 \mathrm{ab}$ & $127.27 \mathrm{c}$ & $80 \mathrm{bc}$ & $83 \mathrm{ab}$ & $83 \mathrm{bc}$ & $86 \mathrm{ab}$ \\
\hline $0.6 \mathrm{ETo}$ & $120.57 \mathrm{c}$ & $116.71 \mathrm{c}$ & $84 \mathrm{ab}$ & 85 a & 87 a & 89 a \\
\hline LSD $5 \%$ & 31.43 & & 4.03 & & 3.41 & \\
\hline
\end{tabular}

Means followed by same letters are not significantly different, LSD 5\% = Least significant difference at $p<0.05$

Significant differences $(p<0.05)$ were found for the chlorophyll content among quantities and the types of irrigation water; however, no significant interaction was found between water types and quantities. Maize irrigated with reclaimed water had significant higher chlorophyll content than fresh water for all levels of water applications. The highest chlorophyll content achieved was 53.23 with the 1.4ETo water quantity which did not significantly differ from the 1.0ETo (51.57), whereas the water quantity

Table 5 Effect of water quantity and quality on green matter yield $(\mathrm{t} / \mathrm{ha})$ of forage maize for two winter seasons

\begin{tabular}{|c|c|c|c|c|c|c|}
\hline \multirow[t]{2}{*}{ Treatments } & \multicolumn{2}{|c|}{ Winter 2006-07 } & \multicolumn{2}{|c|}{ Winter 2007-08 } & \multicolumn{2}{|l|}{ Mean } \\
\hline & RW & FW & RW & FW & RW & FW \\
\hline 1.4ЕTo & 60.79 & 38.89 & 83.44 & 51.74 & $72.12 \mathrm{a}$ & $45.31 \mathrm{bc}$ \\
\hline 1.0ЕTo & 48.76 & 38.95 & 70.04 & 54.21 & $59.40 \mathrm{ab}$ & $46.58 \mathrm{bc}$ \\
\hline $0.6 \mathrm{ETo}$ & 33.54 & 30.97 & 52.72 & 48.96 & $43.13 \mathrm{bc}$ & $39.97 \mathrm{c}$ \\
\hline LSD 5\% & & & & & 19.24 & \\
\hline
\end{tabular}

Means followed by same letters are not significantly different, LSD $5 \%=$ Least significant difference at $p<0.05$
0.6ETo gave the lowest (46.71) (Table 6). The highest chlorophyll content was in plants irrigated with reclaimed water than those irrigated with fresh water type (i.e., 53.94 and 47.07, respectively) (Table 7).

Plants irrigated with the reclaimed water were more efficient in using the water than those irrigated with fresh water in both seasons (Table 6). The analysis of variance showed a significant difference $(p<0.05)$ among the types and quantities of water, whereas there was no significant difference among the interaction of quantity and water type for the water use efficiency of forage maize. The highest water use efficiency was achieved by the 0.6ETo water quantity $\left(3.57 \mathrm{~kg} / \mathrm{m}^{3} \mathrm{DM}\right)$, which did not differ from the 1.0ETo $\left(3.51 \mathrm{~kg} / \mathrm{m}^{3} \mathrm{DM}\right)$ applications. The 1.4 ETo treatments gave the lowest WUE $\left(2.76 \mathrm{~kg} / \mathrm{m}^{3}\right.$ DM) (Table 6) by virtue of the large quantities of water used. In this respected the water use efficiency concept should not be looked upon separately.

No significant differences were observed among the levels of water quantity and their interaction with the water type in the protein content of forge maize. Proteins are 
Table 6 Means of leaf length $(\mathrm{cm})$, chlorophyll content, dry matter yield $(\mathrm{t} / \mathrm{ha})$, and water use efficiency $(\mathrm{kg} \mathrm{dm} / \mathrm{m} 3)$ of forage maize under three water quantities in two winter seasons

\begin{tabular}{|c|c|c|c|c|c|c|c|c|c|c|c|c|}
\hline \multirow{2}{*}{$\begin{array}{l}\text { Water } \\
\text { quantity }\end{array}$} & \multicolumn{3}{|c|}{ Leaf length $(\mathrm{cm})$} & \multicolumn{3}{|c|}{ Chlorophyll content } & \multicolumn{3}{|c|}{ Dry matter yield (t/ha) } & \multicolumn{3}{|c|}{ Water use efficiency $(\mathrm{kg} \mathrm{DM} / \mathrm{m} 3)$} \\
\hline & $\begin{array}{l}\text { Winter } \\
2006-07\end{array}$ & $\begin{array}{l}\text { Winter } \\
2007-08\end{array}$ & Mean & $\begin{array}{l}\text { Winter } \\
\text { 2006-07 }\end{array}$ & $\begin{array}{l}\text { Winter } \\
2007-08\end{array}$ & Mean & $\begin{array}{l}\text { Winter } \\
2006-07\end{array}$ & $\begin{array}{l}\text { Winter } \\
2007-08\end{array}$ & Mean & $\begin{array}{l}\text { Winter } \\
2006-07\end{array}$ & $\begin{array}{l}\text { Winter } \\
2007-08\end{array}$ & Mean \\
\hline 1.4ETo & 78.93 & 84.42 & $81.67 \mathrm{a}$ & 52.43 & 54.04 & $53.23 \mathrm{a}$ & 24.35 & 15.08 & $19.71 \mathrm{a}$ & 2.63 & 2.89 & $2.76 \mathrm{~b}$ \\
\hline $1.0 \mathrm{ETo}$ & 79.99 & 83.92 & $81.95 \mathrm{a}$ & 49.94 & 53.20 & $51.57 \mathrm{a}$ & 22.83 & 14.70 & $18.76 \mathrm{ab}$ & 3.43 & 3.59 & $3.51 \mathrm{ab}$ \\
\hline 0.6ETo & 73.09 & 79.03 & $76.06 \mathrm{~b}$ & 43.68 & 49.75 & $46.71 \mathrm{~b}$ & 15.91 & 11.98 & $13.94 \mathrm{~b}$ & 3.07 & 4.06 & $3.57 \mathrm{a}$ \\
\hline LSD $5 \%$ & 5.31 & & & 2.61 & & & 5.24 & & & 0.85 & & \\
\hline
\end{tabular}

Means followed by same letters are not significantly different, LSD 5\% = Least significant difference at $p<0.05$

Table 7 Means of leaf length $(\mathrm{cm})$, leaf area $(\mathrm{cm} 2)$ and chlorophyll content of forage maize under fresh and reclaimed water irrigation in two winter seasons

\begin{tabular}{|c|c|c|c|c|c|c|c|c|c|}
\hline \multirow[t]{2}{*}{ Water type } & \multicolumn{3}{|c|}{ Leaf length $(\mathrm{cm})$} & \multicolumn{3}{|c|}{ Leaf area $(\mathrm{cm} 2)$} & \multicolumn{3}{|c|}{ Chlorophyll content } \\
\hline & $\begin{array}{l}\text { Winter } \\
2006-07\end{array}$ & $\begin{array}{l}\text { Winter } \\
2007-08\end{array}$ & Mean & $\begin{array}{l}\text { Winter } \\
2006-07\end{array}$ & $\begin{array}{l}\text { Winter } \\
2007-08\end{array}$ & Mean & $\begin{array}{l}\text { Winter } \\
2006-07\end{array}$ & $\begin{array}{l}\text { Winter } \\
2007-08\end{array}$ & Mean \\
\hline Reclaimed water & 79.35 & 84.46 & $81.90 \mathrm{a}$ & 549.96 & 681.32 & $615.64 \mathrm{a}$ & 52.76 & 55.12 & $53.94 \mathrm{a}$ \\
\hline Fresh water & 75.32 & 80.45 & $77.89 \mathrm{~b}$ & 500.23 & 644.51 & $572.37 \mathrm{~b}$ & 44.60 & 49.54 & $47.07 \mathrm{~b}$ \\
\hline LSD 5\% & 4.77 & & & 43.95 & & & 2.74 & & \\
\hline
\end{tabular}

Means followed by same letters are not significantly different, LSD 5\% $=$ Least significant difference at $p<0.05$

Table 8 Means of dry matter yield ( $\mathrm{t} / \mathrm{ha})$, water use efficiency $\left(\mathrm{kg} / \mathrm{m}^{3}\right.$ of dry matter) and protein content $\%$ (i.e., g/100 g) of forage maize under fresh and reclaimed water irrigation in two winter seasons

\begin{tabular}{|c|c|c|c|c|c|c|c|c|c|}
\hline \multirow[t]{2}{*}{ Water type } & \multicolumn{3}{|c|}{ Dry matter yield (t/ha) } & \multicolumn{3}{|c|}{ Water use efficiency $(\mathrm{kg} \mathrm{DM} / \mathrm{m} 3)$} & \multicolumn{3}{|c|}{ Protein $(\%)$} \\
\hline & $\begin{array}{l}\text { Winter } \\
2006-07\end{array}$ & $\begin{array}{l}\text { Winter } \\
2007-08\end{array}$ & Mean & $\begin{array}{l}\text { Winter } \\
2006-07\end{array}$ & $\begin{array}{l}\text { Winter } \\
2007-08\end{array}$ & Mean & $\begin{array}{l}\text { Winter } \\
2006-07\end{array}$ & $\begin{array}{l}\text { Winter } \\
2007-08\end{array}$ & Mean \\
\hline Reclaimed water & 23.14 & 15.81 & $19.48 \mathrm{a}$ & 3.30 & 4.00 & $3.65 \mathrm{a}$ & 11.91 & 12.25 & $12.08 \mathrm{a}$ \\
\hline Fresh water & 18.91 & 12.02 & $15.47 \mathrm{~b}$ & 2.79 & 3.03 & $2.91 \mathrm{~b}$ & 9.11 & 12.18 & $10.64 \mathrm{~b}$ \\
\hline LSD 5\% & 2.64 & & & 0.44 & & & 1.31 & & \\
\hline
\end{tabular}

Means followed by same letters are not significantly different, LSD 5\% = Least significant difference at $p<0.05$

large molecules required for the structure, function, and regulation of the plant tissues. However, a significant difference $(p<0.05)$ was found among the quality of irrigation water applied. The plants irrigated with the reclaimed water contained a significantly $(p<0.05)$ higher percentage of protein $(12.08 \%)$ than those irrigated with fresh water $(10.64 \%)$ (Table 8$)$. The analysis of variance showed a higher nitrogen percentage in reclaimed water compared with fresh water, which explains the increase of protein in the plants irrigated with the reclaimed water as reported by Ferreira da Silva et al. (2005) and Tavassoli et al. (2010). This suggests that a future study could be done to assess the levels of soil nitrogen, potassium, and calcium.

In a related study, Ahmad et al. (2011) assessed the effect of sewage water treatments on accumulation of heavy metals $(\mathrm{Pb}, \mathrm{Cd}$ and $\mathrm{Cr})$ in canola (Brassica napus L.). Sewage water application had a significant effect on number of leaves and leaf area. They observed a decline in yield in the treated crop. This is in contrast to the current study where plants irrigated with reclaimed water had higher development rates in comparison with those irrigated with fresh water (Figs. 1,2) and also gave higher green forage yield than fresh water type (Table 5). This can be attributed to the higher nutrient content of the reclaimed water (i.e., see nitrogen and sulfate in Table 2), and possibly due to the higher water salinity of the fresh water (i.e., $1.29 \mathrm{dS} / \mathrm{m}$ compared with $1.11 \mathrm{ds} / \mathrm{m}$ for reclaimed water). A higher salt content would have an inhibitory effect on crop growth. We can speculate that future studies with reclaimed water should put greater emphasis on assessing the effect of water quality on crop growth, yield, and composition. Qadir et al. (2010) noted that public policies are also needed to motivate better the management of reclaimed water. Furthermore, Holgate et al. (2011) 
reported that graywater recycling and rain water harvesting for irrigating urban and suburban landscapes should reduce the use of potable water in arid and subtropical climates.

\section{Conclusions}

Plants irrigated with the reclaimed water had higher plant height than those irrigated with the fresh water. Reclaimed water had shorter time for $50 \%$ male and female flowering of forage maize plants, indicating earlier maturity. Plants irrigated with reclaimed water had higher chlorophyll content for all levels of water applications. A significant difference in green forage yield was found among the interactions. Reclaimed water gave the highest green forage yield. Plants irrigated with the reclaimed water used water more efficiently than those irrigated with the fresh water for all water quantities. The enhanced growth in wastewater-irrigated crops, compared with freshwaterirrigated crops, was attributed primarily to higher nutrient content (e.g., nitrogen) and lower salinity of the reclaimed water. It was recommended that future studies be done on cost-benefit analysis on the use these crops as animal feed. More in-depth evaluation of possible crop and soil contamination was also recommended.

Open Access This article is distributed under the terms of the Creative Commons Attribution License which permits any use, distribution and reproduction in any medium, provided the original author(s) and source are credited.

\section{References}

Abaidoo RC, Keraita B, Drechsel P, Dissanayake P, Maxwell AS. (2010) Soil and crop contamination through wastewater irrigation and options for risk reduction in developing countries. In: Dion P (ed) Soil biology and agriculture in the tropics, Soil biology 21, pp 275-297

Abdelrahman AH, Al-Ajmi H (1994) Heavy metals in some water and wastewater irrigated soils of Oman. Commun Soil Sci Plant Anal 25(5/6):605-613

Abdelrahman AH, Al Yafie BA, Goosen MFA (2009) Evaluation of environmental factors and equipment configuration on efficiency of a solar soil water collector. Int J Environ Technol Manag 10(3/4):260-274

Ahmad K, Ejaz A, Azam M, Khan ZI, Ashraf M, Al-Qurainy F, Fardous A, Gondal S, Bayat AR, Valeem EE (2011) Lead, cadmium and chromium contents of canola irrigated with sewage water. Pak J Bot 43(2):1403-1410

Akhtar M, Nadaf SK (2002) Consolidated results of the experiments in field crops (1971-2000) Directorate General of Agriculture, Ministry of Agriculture and Fisheries. Sultanate of Oman

Alade GA, Ojoawo SO (2009) Purification of domestic sewage by water- hyacinth (Eichhornia crassipes). Int J Environ Technol Manag 10(3/4):286-294

Alessi J, Power JF (1976) Water use by dryland corn as affected by maturity class and plant spacing. Agron J 68:547-550
Bouchaib EH, Handoufb A, Mekraneb M, Touzanib M, Khanac A, Khallayounea K, Benchokround T (1999) Use of wastewater for crop production under arid and saline conditions: yield and hygienic quality of the crop and soil contaminations. Water Sci Technol 33:10/11:327-334 http://www.sciencedirect.com

Carr G, Potter RB, Nortcliff S (2011) Water reuse for irrigation in Jordan: Perceptions of water quality among farmers. Agric Water Manag 98:84-854

Chapman HD, Pratt FP (1982) Methods of analysis for soils, plants and waters. Division of Agricultural Sciences, University of California, USA. Pub. No. 4034

Chenini F (2011) Evaluation of three decades of wastewater reuse in Tunisia. In: Barcele D, Petrovic M (eds) Waste water treatment and reuse in the Mediterranean region. Hdb Environ Chem 14:215-227. Doi:10.1007/698_2010_65

da Fonseca AF, Melfia AJ, Montes CR (2005) Maize growth and changes in soil fertility after irrigation with treated sewage effluent. II. Soil acidity, exchangeable cations, and sulfur, boron, and heavy metals availability. Commun Soil Sci Plant Anal 36(13/14):1983-2003

Dorenbos J, Pruitt WO (1992) Crop water requirements-guidelines for predicting crop water requirements. FAO Irrigation and Drainage Paper 24, FAO, Rome

Evanylo G, Ervin E, Zhang X (2010) Reclaimed water for turfgrass irrigation. Water 2:685-701

Ferreira da Silva PR, Strieder ML, da Silva Coser RP, Rambo L, Sango L, Argenta G, Forsthofer EL, da Silva AA (2005) Grain yield and kernel crude protein content Increases of maize hybrids with late Nitrogen side-dressing. Sci Agric (Piracicaba, Braz.) 62(5):487-492

Galavi M, Jalali A, Ramroodi M, Mousavi SR, Galavi H (2010) Effects of treated municipal wastewater on soil chemical properties and heavy metal uptake by sorghum (Sorghum Bicolor L.). J Agric Sci 2:235-241

Gomez KA, Gomez AA (1984) Statistical procedures for agricultural research, 2nd edn. The International Rice Research Institute, Philippines

Holgate LC, Aitkenhead-Peterson JA, Gentry TJ (2011) Irrigation water chemistry: impact on microbial community composition and biogeochemical leaching under perennial ryegrass (Lolium perenne [L]). ISRN Ecology 2011. doi:10.5402/2011/ 797910

Merrill AL, Watt BK (1973) Energy value of foods, basis and derivation. United States Department of Agriculture Handbook 74. USDA, Washington, DC

Mohamed SA (1983) Effect of irrigation water and fertilization on yield and water use efficiency of corn plants in Fayoum Governorate. (Egypt). Ann Agric Sci, Moshtohor 20:221-233

Mohammad MJ, Ayadi M (2004) Forage yield and nutrient uptake as influenced by secondary treated wastewater. J Plant Nutr 27(2):351-365

Mohammad MJ, Mazahareh N (2003) Changes in soil fertility parameters in response to irrigation of forage crops with secondary treated wastewater. Commun Soil Sci Plant Anal 34(9/10):1281-1294

Monson RK (1989) The relative contributions of reduced photorespiration, and improved water and nitrogen use efficiency, to the advantages of C3-C4 intermediate photosynthesis in Flaveria. Oecologia (Berlin) 80:215-221

MRMEWR (2005) Water resources in Oman, ministry of regional municipalities, environment and water resources. An edition in the occasion of the 35th National Day. November 2005. Muscat, Sultanate of Oman

Musik JT, Duesk DA (1980) Irrigated corn yield response to water. Trans ASAE 23:92-98 
Parsons LR, Sheikh B, Holden R, York DW (2010) Reclaimed water as an alternative source for crop irrigation. Hort Sci 45(11): $1626-1629$

Qadir M, Wichelns D, Raschid-Sally L, McCornick PG, Drechsel P, Bahri A, Minhas PS (2010) The challenges of wastewater irrigation in developing countries. Agric Water Manag 97(4): $561-568$

Rhoads FM, Bennett JM (1990) Corn. In: Stewart BA, Nielsen DR (eds) Irrigation of agricultural crops. Madison, WI: ASA, CSSA, and SSSA, Agron Monogr 30:569-596

Tavassoli A, Ghanbari A, Amiri E, Paygozar Y (2010) Effect of municipal wastewater wastewater with manure and fertilizer on yield and quality characteristics of forage in corn. African Journal of Biotechnology Vol 9(17):2515-2520

Vazquzio O, Horan NJ, Mara DD (1996) Management of domestic wastewater for reuse in irrigation. Water Sci Technol 33(10/ 11):355-362

Wu CC, Margulis SA (2011) Feasibility of real-time soil state and flux characterization for wastewater reuse using an embedded sensor network data assimilation approach. J Hydrol 399(3/ 4):313-325

Yanuka M, Leshem Y, Dovrat A (1982) Forage corn response to several trickle irrigation and fertilization regimes. Agron $\mathbf{J}$ 74:736-740 